\title{
MULTI-SENSORY APPROACHES TO (AUDIO) DESCRIBING THE VISUAL ARTS ${ }^{1}$
}

\author{
Josélia Neves \\ Instituto Politécnico de Leiria (Portugal) \\ joselia.neves@ipleiria.pt
}

\begin{abstract}
Making art accessible to blind patrons requires the ability to convey explicit and implicit visual messages through non-visual forms. Audio description is often seen as the best way to offer visual texts to blind people; however, one may query whether words alone are sufficient to convey the subtleties of art and to transport the emotional charge such works offer. It is a fact that the dialogue between words and touch may allow these particular "readers" to "see" art in its tangible forms, but perhaps more is needed if one is to give them the opportunity to live the art experience to the full. This article discusses different multi-sensory approaches to making art available to visually impaired people and proposes soundpainting as a form of artistic transcreation.
\end{abstract}

\section{Resumen}

Para que el arte sea accesible para las personas ciegas es necesario saber transmitir mensajes visuales, tanto explícitos como implícitos, a través de formas no visuales. La audiodescripción se considera, a menudo, como la mejor manera de ofrecer textos visuales a los ciegos; sin embargo, uno se puede preguntar si las palabras por sí solas son suficientes para transmitir las sutilezas de las artes visuales y transportar la carga emocional de estas obras. Es cierto que el diálogo que se establece entre las palabras y el acto de tocar puede permitir a estos "lectores" particulares "ver" obras artísticas en sus formas tangibles, pero quizás se necesite más si el objetivo último es brindarles la oportunidad de disfrutar la experiencia artística en todas sus dimensiones. En este

1. This research has been partially funded by the European Project AD LAB: Audio Description. Lifelong Access for the Blind with reference no. 517992-LLP-1-20111-IT-ERASMUS-ECUE. 
artículo se analizan varias aproximaciones multisensoriales encaminadas a conseguir que las artes visuales sean accesibles a las personas con discapacidad visual y propone el soundpainting como una forma de transcreación artística.

Keywords: Audio description. Audio guides. Soundpainting. Museum. Visual arts. Accessibility.

Palabras clave: Audiodescripción. Audioguías. Soundpainting. Museo. Artes visuales. Accesibilidad.

Manuscript received on July 18, 2011; Definitely accepted on November 15, 2011. 
Art stimulates perception, thought, feeling, physicality, spirit. (Meredith Monk)

\section{Blindness and the Museum}

When one faces the long winding queues at the Museo del Prado, in Madrid, at the Louvre, in Paris, or the Accademia di Bella Arti, in Florence, one can only wonder what makes people want to visit art museums. In general terms, Van den Berg Haarlem (2008) believes that museums raise in their visitors feelings of two kinds: personal feelings and social feelings. This museum marketing professional believes that, on a personal level, visiting museums can develop a feeling of entertainment, "being entertained feels good, you feel joy and fun"; of education, "understanding how things work, solving a puzzle, raises your self esteem"; and of aesthetics, "the awe of seeing a great object of art, is uplifting, it stretches the imagination, it crosses a mental boundary". On a social level, it might involve the heightened thrill of sharing feelings, "seeing the same beautiful work of art, and sharing that feeling enhances the aesthetical feelings"; or those of superiority or inferiority in which people measure themselves to the standards of their peers; at times, when "others decide for you to go, like in a school trip", such social feelings are simply lethargic; but they can also be that of the landmark when each experience is one of "a once in a life time event".

When art is the focal point, there are reasons to believe that a new set of feelings come into play because, as Mock (1990) puts it:

art offers something else - depth, involvement, a new way of looking at the world that we live in, a fresh approach to what we take for granted, a chance to experience freedom of the imagination. (...) Art becomes a paradigm for whole, integrated human beings using the fullness of their resources as artists and as audiences.

So, whatever the reasons for visiting, when art is at stake, in museums, people are given the opportunity to go on personal journeys brought about by a dialogue between each work and its beholder. But what happens when the beholder cannot access the work of art for the simple fact that $\mathrm{s} / \mathrm{he}$ is blind 
or has low vision? Does this mean that the art experience is off boundaries for people with visual impairment? Why would a blind person want to visit an art gallery, or a museum of any sort, in a time when museums are mainly visual experiences?

Smith (2003: 221) highlights the fact that there is no difference between sighted and blind museum goers when he responds that:

[t]hey may simply want to be in the presence of great art, great scientific achievement, important historical objects or documents, anthropological and archeological findings and specimens, or multi-cultural information of all kinds. [...] whatever the reason, a visually impaired person hopes to leave the museum fully enriched by the experience.

Even in the context of visually oriented museums, the key to enriching experiences can easily be found in the provision of alternative means of access that may lead to similar effects. To this Smith testifies (ibid.: 222) in the first person, "[b]y using vivid description, and engaging my senses of touch, hearing and smell, they are able to give me a greater level of access than they would to many researchers with sight."

Multi-sensory communication is still a fairly novel concept that is bound to change the world of multimedia in the near future. Sensitizers, smellitizers and sense stimulating gadgetry are already in use in theme parks - e.g. the Horizon experience at Disney's Epcot center (Epcot Central 2008), but haven't yet found their way into museums at large. However, in practice, and through solutions such as those referred by Smith (op.cit.), visitors are already being offered multi-sensory experiences either through carefully set up exhibitions or through special (live or electronic) guided tours, touch sessions and oriented workshops.

At present, the most common multi-sensory experiences at museums are made available to visually impaired visitors through one of the following solutions: special exhibits/museums that have been devised with them in mind (e.g. Anteros Museum, in Bologna, or the Museo Tiflológico, in Madrid); special live tours/touch sessions (e.g. V\&A or the British Museum in London) that take visitors with special needs as their main addressees; or specific audio guides (e.g. Winston Churchill Museum and recently the British Museum, in London) that have specially made descriptions for blind users. In most cases, these solutions resort to words and touch to help blind patrons "see" the exhibits, a solution which becomes particularly complex when the visual arts are involved.

In simple terms, works in the visual arts are either tri-dimensional or bidimensional. Tri-dimensional art, such as sculpture, is theoretically readily 
available to touch even though it is mainly to be seen. In those cases, one may think that words are dispensable or merely an extra. Bi-dimensional art, such as painting, drawing or photography, which are in essence purely visual, is a real challenge both to visually impaired visitors and to conveners who wish to make them accessible to as many visitors as possible. In these cases, words often take the lead and audio description is called upon to present or describe the exhibits.

One might say that audio description is inherent to the art experience in many museums throughout the world. Every time (human) guides lead visitors through art galleries, filling in information about the exhibits, calling attention to details or discussing technique and style, they are using language to make the art experience meaningful. However, conventional (live or electronic audio guided) tours to museums are mostly directed towards sighted visitors for they serve to direct the gaze and to highlight the elements that make each exhibit special. In such circumstances language is used as a go-between; it helps the less knowledgeable to understand the work of art, enhances interest, or simply adds the social element to an experience that, otherwise, would be more solitary and probably less enjoyable. When visually impaired patrons join in, what is said is what is seen, so words gain special importance. Words can become the art experience itself, a situation that is particularly true when no alternative haptic, i.e. hands-on solutions have been provided.

Not many art galleries offer especially conceived audio guides for visitors with visual impairment. Perhaps this is the case because there is a belief that blind people will not be interested in the visual arts; there has been no real demand for the service; or simply because curators do not know how to go about promoting the true inclusion of visually impaired patrons. A sign that things are changing is the fact that more and more museums are being creative and are now providing alternative solutions for visitors with special needs and that commercially based companies providing content for audioguides now advertise specific audio description for blind visitors. However, such contents are far and few and at a time when there is a growing demand for special solutions, in line with the Civil Society Platform on Access to Culture - "Policy Guidelines" (EU 2009), more needs to be done, and a lot can be learnt by analysing what is already in place.

\section{The tailor-made experience - a personal narrative}

Anybody visiting the Anteros Museum (Museo tattile di pittura antica e moderna Anteros), in Bologna, is bound to come away with an unforgettable experience and many lessons learned about making the visual arts available 
to people with visual impairment. This special venue is unique in that it holds plaster cast tactile versions of over 40 masterpiece painting of all times, especially made so that blind people can "see" them through touch. Visits are planned and booked ahead and only one masterpiece is addressed each time. Each experience is a personal narrative. Elena's story encapsulates one of those experiences:

Elena is now 23 and has been blind since birth. At school she learned all about history and art; she knows that paintings are naturally directed towards sighted people, but she feels she too can come to know them better. She knows that here she will be able to "see" paintings that are hanging in the Louvre, in Paris; in the National Gallery, in London; in the Musée Royaux des Beaux Arts, in Brussels; or as far as in the National Gallery of Tokyo. She also knows the "paintings" at the Anteros Museum have been especially designed for people like her, people who "have to" or "choose to" see through touch and through hearing. Elena knows that her experience is one that can never match that of looking at the original work of art in its actual setting, but she also knows that here she will be able to see for herself, even if in an environment that does not have the makings of traditional art galleries.

The Anteros Museum has one main room open to the public and presents itself as an educational platform, whose aim is to disseminate and develop knowledge both among blind and sighted persons. In its website (http://www. cavazza.it/museoanteros/) one may read, "to know how to see with the hands and touch with the eyes means, whether for blind or sighted persons, that preconceptions cease to be an issue in order to freely learn about the real beauty of things." By proposing to offer visual art through tactile solutions, the Anteros Museum is proposing multi-sensory experiences that can make the perception of art richer for visually impaired and sighted visitors alike. This is done with the knowledge that there are distinct differences between what is perceived through the different senses. As Secchi (n/d), the museum's curator, puts it,

[t] he starting point of this process is education to constant improvement of visual, tactile and ideally[synaesthesic] senses, by taking into account all inevitable variations and corrections aimed at partially filling the visual deficit.

[...] This is not meant to find a simplistic equivalence between optic and tactile perception but rather to identify some common ground between the organisation of optic and haptic visual processes.

2. The name "Elena" is fictitious, but the facts are exact and the experience/exercise was witnessed during a research visit to the Anteros, in 2009. 
By watching Elena's visit to the Anteros, a number of interesting questions come to the fore in matters pertaining to making art accessible to visually impaired people and many more in the domain of audio description for the visual arts.

Elena was warmly welcomed by the museum team: the curator and a (legally blind) guide. All parties agreed on the picture to be addressed in that particular visit: The Lamentation over the Dead Christ (1480), a painting by the Italian renaissance painter Andrea Mantegna. She was led to her seat, in front of a table on which a three dimensional to-size-plaster-cast-picture was propped. Elena knew exactly how to place herself and was soon touching the picture freely. She knew nothing about the picture when she arrived. The only cue she had on which to build expectations was the title of the painting and the fact that it was a work by Mantegna. Had she known other works by this painter or even by painters of the same period, she might have brought in the previous knowledge when she was asked to say what she could make of the painting through touch alone. But she had very little on which to build her tactile perception. And she found very few words to express what she thought she was feeling. The complex compositional whole, the unexpectedness of the viewpoint and the effect of perspective compression makes this painting particularly difficult to discern through touch alone and Elena ventured a few loose utterances: "waves... the sea?... are these feet? ... there is somebody here (in the top left hand corner)...". Left on her own, and through touch alone, there was very little she could "see". She was soon to be rescued when her hands were taken and guided to explore the painting, little by little, to the sound of words.

She was first invited to take in the whole as she circled the frame to get the picture's overall dimension. She was then offered a focal point from which to build on, the feet; and she was conducted, little by little, making sense of perspective, to explore every detail, minutely carved in the bas relief. Her face lit up every time she made sense of what a few minutes before her fingers had made very little of.

Her hands and fingers were gently but firmly guided to explore every detail and she was invited to take on the posture of the weeping women, re-enacting their pose with her own body. But the picture only came to life through language. Words were used in profusion. Some were denotative and talked of size, shape and location; others were technical and spoke of style and perspective; others were descriptive and filled in what the white plaster did not have: colour and visual texture; and many more spoke of emotions 
as they told stories that were obviously built upon culture and lore ${ }^{3}$. Elena spoke little, but when she did, she wanted to know more about the feeling or feelings the original evoked. It was clear that she was building mental images that were far beyond the ones she could certify through touch. If initially words were used to supplement touch, as the visit progressed, touch just gave body to words, and close to the end of the visit, the hands rested and words alone took over and a free dialogue took place. The conversation came and went, to and from the work of art under scrutiny. Knowledge from previous experiences and other fields were conveyed and the experiential whole became relational rather that circumstantial. Elena was clearly integrating the newly acquired knowledge with that which she had brought with her to this exercise. She was living the art experience like any sighted person would have done; only that she had taken over an hour to do it and she probably went deeper than a sighted visitor to the Pinacoteca di Brera, in Milan, where the original is hanging, would have gone.

The unique setting of this particular visit encapsulates many of the issues that need to be discussed when addressing access to culture in general and when addressing the importance of audio description for access to the visual arts in museums at large. Elena's visit had the makings of an (almost) ideal visit to an art museum. The Anteros Museum has taken down the main barriers to inclusion, as proposed by Dodd \& Sandell (1988: 14) by guaranteeing physical, sensory, intellectual, financial, emotional/attitudinal, decisionmaking, information and cultural access to its visitors. Elena had total ease in finding and arriving at the museum; she was made welcome and was given full individual attention; she didn't have to pay for her visit; her visit was tailor-made to her specific needs and she was the one to "lead" her own experience even if she was to be led by those guiding her visit; she was given access to information and culture to a measure that she might not be given had she visited the actual venue where the original is presented. Despite the privileged almost-perfect-situation, Elena was not to experience the emotion of living the art experience to the full. Like any other museumgoer, Elena would have preferred to face the original painting in loco, at the museum where it is exhibited, most probably in the company of family or friends. Even though she was given full attention and the artwork was described until she was perfectly satisfied, she did not get the chance to preserve her identity and to live her personal and social art experience in full privacy. Elena's experience

3. A written version of the verbal guide can be found in http://www.cavazza.it/museo anteros/index.php?nav=Lamento\%20Cristo\%20morto.none26 
was, above all, and in tune with the museum's aims, pedagogical rather than entertaining. As mentioned before, Elena is a regular visitor to the Anteros Museum, and clearly enjoys her visits, but her regularity is one that derives of her special needs, to which here alone she finds a response. Just like the Museo Tiflológico (http://museo.once.es/), in Madrid, the Anteros Museum is specifically directed towards visually impaired visitors and takes on a very strong social and educational role. Even though both venues stimulate visits by non-visually impaired patrons, their main focus is openly placed in providing rewarding experiences to that specific group of people. In the case of the Anteros Museum, the art forms that are made accessible are problematic in their very nature. Paintings are meant to be seen and making them accessible to visually impaired people might be challenging, but by no means impossible. If museums were only to make a few of their exhibits accessible in the lines of what these two specilised museums do, they would be opening their doors to a group of people who are forced by their personal circumstances to be excluded from most cultural venues. And in view of Elena's experience, it might not be that difficult to find interesting solutions for what is still seen by many as a great problem. One of the most interesting (and democratic) solution might be had in audio guides.

\section{Audio guides to promote multi-sensory art experiences}

Audio guides were first introduced in museums in the 50s, taking on from the guidebook which, at the time, was the main portable interaction medium available to visitors. Printed material still holds valid in the present context and can even be a precious aid to visitors with disabilities. Such materials can be printed in different formats, sizes and can even allow for the tactile experience. Further to materials in Braille, many museums now offer simplified versions of some of their works of art on swell paper (microcapsule paper), with which blind visitors can feel the main contours of the elements in any picture, thus perceiving shapes, layout, perspective and proportion. When used in conjunction with other solutions, such as audio description, these raised diagrams can be interesting aids to make the visual arts more tangible. The importance of providing words (in print or via speech) to make sense of such printed materials is very obvious, particularly when the users are not acquainted to the technicque or simply are not given other contextual information with which to decode the raised images. As with other printed material, people need to learn how to "read" tactile materials and this process can be made easier with the aid of audio description to help guide the fingertips. 
The audio guides that are available in most museums, and even those that have been conceived for blind visitors, do not serve to guide people's hands in the tactile experience. They normally limit themselves to providing a description of the work and this will either take the person to look at the picture in a particular way - in the case of audio guides for sighted people -, or simply provide a description that might allow blind people to create an image in their mind's eye. Tactile experiences such as Elena's or those using raised images are particularly challenging because reading through touch is time consuming and pre-recorded material to aid touch experiences will need to take that element into account and it is not easy to determine how much time is needed to explore and to take in the combined experience of sound and touch. Rebecca McGinnis, access coordinator at the Metropolitan Museum of Art, NYC, explains in Art Beyond Sight (n/d) that exploration through touch takes time because

touch is sequential, not instantaneous, because you have to touch each part of a sculpture and build up an idea of it. It takes a lot longer; it's more taxing to the memory, distraction is a bigger issue perhaps.

The question remains, how can touching a piece and listening to a audio guide go together in adequate synchrony when each will necessarily require different time frames? This can only be achieved through interactive audio guides.

Technology has come a long way since, in 1952, Sandberg first used a closed-circuit short wave radio broadcasting system to deliver pre-recorded audio guides to people visiting Amsterdam's Stedelijk (municipal) $\mathrm{Mu}$ seum. In fact, under the umbrella term of "audio guide" we can presently list a number of different solutions that span from the touch/push buttoned wand systems to the mp3 player, whilst passing through podcasts that can be downloaded into mobile phones and PDAs, containing sound and/or image and with a greater or lesser degree of interaction. Museums often make their choices on the basis of the costs involved and of the type of contents that they wish to make available. Where blind patrons are concerned it makes great sense to find a solution that will leave hands free both to hold the cane or the guide dog's leash and/or to touch anything available. In general, visitors are expected to press a number that identifies each audio described element. This task is particularly difficult for people who cannot actually see such numbers and audio signposting becomes essential. Museums with infra-red or wifi systems are now offering automatic Line of Sight Aware Systems, making the audio/video go on when visitors approach the object in case. These systems can be sophisticated and not many museums have the dimension or the means 
to use technology that is complex in its set up yet flexible to use. In a not so far away ideal world, museum guides will be flexible and dynamic enough to adapt to the needs of each visitor, who can select beforehand the kind of visit they want to experience, the type of (audio/video/multimedia) content they wish to use, and even have special materials printed out either to use during the visit or to take home with them. Downloadable contents, made available using web solutions, are soon bound to become widely available in museums, cutting down costs and creating greater opportunities for all alike. By breaking down technological barriers, and by bringing in the tendencies of the Web 2.0 and Web 3.0 collaborative culture, museum guides will become freely available and what was once the field of highly specialised professionals is soon to be democratised and made by many. In the line of what fansubbers did for the film industry, informal curators are now providing dowloadable ipod audio guides free of charge for anybody to use. Art Mobs producing audio guides for MoMA (New York's Museum of Modern Art) state their case (Glibert 2005):

We've produced (unofficial) audio guides for MoMA, and we're making them available as podcasts. 'The mission of Art Mobs is to explore the intersection of communication, art, and mobile technology.' With the near ubiquity of iPods and other portable MP3 players, the platform is already out there, in our bags, our coat pockets, on our belts.

What started off as a class project has given way to open source audio guide production, an example that is inspiring museum lovers everywhere. Just as happens with live tours that are sometimes run by volunteer guides - arts students or friends of the museum - art mobs are usually equally enthusiastic connoisseurs who offer their time and knowledge in exchange for the experience of sharing their love for the subject with other physical or virtual visitors. Though it may be true that in most cases people who venture to produce audio guide contents are in total command of the subject matter, they do not necessarily have the technique or linguistic ability to make audio guides that are simultaneously informative and entertaining. This is particularly the case when the audio guides are to be used by blind people and even more so when the audioguide is not only meant to describe visuals but are also to guide people's hands in the haptic experience of the arts.

\section{Sound and touch making sense of art}

Anybody wishing to make the visual arts available to the blind via audio description is bound to follow set and tried guidelines as those proposed by the 
Art Beyond Sight Project ${ }^{4}$. The AEB guidelines (Axel et al. 1996) state that audio described museum tours should cover the following elements: (1) present standard information "found on a museum's object label: artist, nationality, title, date, mediums, dimensions, and the custodian or location of the work"; (2) give a general overview of subject, form, and colour, providing "visual information in a sequence, allowing a blind person to assemble, piece by piece, an image of a highly complex work of art"; (3) give orientation with directions specific and concrete information "to indicate the location of objects or figures in a work of art"; (4) mention the importance of the technique or medium, to enable the blind viewer "to understand the ways in which meaning, style, or both are generated from the materials"; (5) focus on style by "referring to the features that identify a work as being by a particular artist or school, or of a movement, period, or geographical region"; (6) use of specific words avoiding "ambiguous and figurative language"; (7) provide vivid details with "enough information so that listeners can form an image in their minds, and come to their own opinions and conclusions about a work of art"; (8) indicate where the curators have installed a work and say "how the work under discussion relates to these other works, as well as to the viewer and the surrounding space"; (9) refer to other senses as analogues for vision to enable blind viewers to "construct highly detailed impressions of a work of visual art"; (10) explain intangible concepts with analogies even when "visual phenomena, such as shadows or clouds, may be difficult to describe objectively"; (11) encourage understanding through reenactment, allowing "the blind person to mimic the depicted figure's pose"; (12) provide information on the historical and social context; (13) incorporate sound in creative ways: (14) allow people to touch artworks because "direct touch is the best way to explore an object"; (15) provide alternative touch materials or (16) tactile illustrations of artworks, normally "black-and-white relief images are schematic diagrams, and they do not represent the actual object in every detail".

Very much in line with the established guidelines and with the knowledge of experience, De Coster \& Mühleis (2007: 193) put together a proposal for a two tier (intersensorial) type of audio description that in practice sums up to three distinct phases:

First, establish a geometrical structure as a frame of reference, and then refer back to this structure later on in the description, i.e. describe the painting in relation to it. Next, proceed to describe the signs that are clear or relatively

4. Full text available at: http://www.artbeyondsight.org/ (last access on July 12, 2011). 
unambiguous before tackling the ambivalent signs, if this is possible given the picture chosen.

The audio description that De Coster and Mühleis (ibid.) propose divides the visual message into objective, tangible elements and subjective, intangible elements. In so doing they have brought to the fore one of the main features of art - ambiguity -, which they believe to be untranslatable through words. However, they add that "one can give an idea of visual ambiguity [...] if a comparable ambiguity exists in another sensorial field (touch, hearing)".

De Coster and Mühleis' premise is complex but productive. It leads one in the direction of what word painting (also known as "tone painting" or "text painting") does in music, in which the musical technique reflects the literal meaning of the song (i.e. music translates the meaning of words). However, these authors are suggesting that the ambivalent (visual) signs that are difficult to be translated into words can have their meanings explained (still through words). This reads as somewhat contradictory, in that the audio describer will be interpreting, explicitating and giving meaning to signs that are meant to be kept ambiguous.

This approach is also contrary to that of audio description for film, for instance, in which ambiguity and subjectivity are to be avoided at all costs. It may be defensible that in films audio description should add "precise, concise verbal descriptions of visual images - about people, objects, scenes, body language, facial expressions, sizes, and colors" (Schmeidler $\&$ Kirchner 2001: 197); however, when addressing works of art, in which creativity and subjectivity are central, audio description necessarily needs to be addressed in a different manner.

De Coster and Mühleis' proposal could be understood in a quite different manner if instead of explaining the meaning of the ambivalent signs, audio describers could find in words the same "sensorial ambiguity" that is said to be found in sound or touch. This different approach could be addressed as "soundpainting" or even poesis much in line with the ekphrastic tradition. Ekphrasis, which Pujol \& Orero (2007: 49) define as "a literary figure that provides the graphic and often dramatic description of a painting, a relief or other work of art", can include "elements that can be considered objective, whereas other elements are completely subjective" (ibid.: 53), serving both the "clear signs" and "ambivalent signs" that works of art are made of. If ekphrasis is a "poetic description of a pictorial or sculptural work of art" (Spitzer 1962: 72), audio description that wants to suggest rather than to explicitate might find a solution just there. 
It may be risky to be poetic when describing painting, particularly because, as Da Vinci wrote in his notebooks, words are never as strong as images. In the effort to show how painting is superior to poetry Da Vinci (653, in Richter 1880) writes:

though the poet is as free as the painter in the invention of his fictions they are not as satisfactory to men as paintings; for though poetry is able to describe forms, actions and places in words, the painter deals with the actual similitude in the forms, in order to represent them.

However, if the blind person cannot have direct access to the work itself, might it not be better to be given an "alternative work of art" to look at through the other senses? People who cannot see the work of art will not be able to relate to it as sighted people would do unless they gain access to the explicit and the implicit meanings the piece conveys. Furthermore, art is expression, and conveying the expressive nature of any work of art through words alone may be truly challenging. If only explicit signs can be expressed through words, then ways must be found to convey the feelings and sensations that are only invoked or raised through feelings. Soundpainting does that by bringing together multiple sound "textures". Carefully chosen words and a careful direction of the voice talent to guarantee adequate tone of voice, rhythm and speech modulation can all work together with specific sound effects and music to provide the "story(ies)" and emotions that a particular piece of art may offer. In many ways, soundpainting goes against the grain of conventional museum audiodescription, particularly for being openly subjective and interpretative in nature. By trying to capture and recreate artistic subtleties, it might be seen as a form of transcreation, particularly because it aims to "substitute" the original form by an equivalent and yet new art form. Balemans' (2010) account of transcreation is relevant to soundpainting in that:

[t]ranscreation is used to make sure that the target text is the same as the source text in every aspect: the message it conveys, style, the images and emotions it evokes and its cultural background. You could say that transcreation is to translation what copywriting is to writing.

In a similar manner to the transcreation strategies found in the realm of marketing, in the context of the visual arts, a visual text can give way to a new sound-based multi-sensory text that recreates the style and emotions of the first, suggesting, guiding people through tactile readings (should there be a tactile reproduction to be used) and yet still allowing for interpretation and the "rewriting" of yet another personal text. Despite the fact that soundpainting may be interpretative or subjective in nature, it can still be loyal to the 
original piece of work in its effort to convey the messages and emotions of the first through new modes of expression.

Whichever the option taken towards making art accessible to blind patrons - live descriptions, audio guides with conventional (neutral) audio description or expressive soundpainting, a special effort must be made if one is to offer purely visual art through the sense of hearing and of touch. Providing equivalent effects through apparently opposite means of communication is a challenge that requires inventiveness and artistic competencies that go well beyond the use of words. Complex multimodal, multi-sensory solutions are bound to offer richer experiences to blind and sighted people alike when museum professionals or translators are called upon to transcreate the essence of art.

\section{References}

AXEL, Elisabeth Salzhauer et al. (1996) AEB's Guidelines for Verbal Description Adapted from Making Visual Art Accessible to People Who Are Blind and Visually Impaired, Art Education for the Blind. Full text version at: http://www.artbeyondsight.org/handbook/acs-guidelines.shtml (retrieved on July 12, 2011).

Balemans, Percy. (2010) Transcreation: translating and recreating. (July 14, 2010) Full text version at: http://pbtranslations.wordpress.com/ (retrieved on July $12,2011)$.

DE COSTER, Karin \& Volkmar Mühleis. (2007) "Intersensorial translation: visual art made up by words". In: Diaz Cintas, Jorge; Pilar Orero \& Aline Remael (eds). Media for All. Subtitling for the Deaf, Audiodescription, and Sign Language. Amsterdam \& New York: Rodopi. pp. 189-200.

DoDD, Jocelyn \& Richard Sandell. (1998) Building Bridges. Guidance for museums and galleries on developing new audiences. London: Museums \& Galleries Commission.

Epcot Central. (2008) A Smell of Orange. ( January 30, 2008) Full text version at: http://epcot82.blogspot.com/2008/01/smell-of-orange.html (retrieved on November 27, 2011).

Gilbert, David. (2005) Art Mobs to Remix MoMA (With Your Help). (May 11, 2005). Full text version at: http://mod.blogs.com/art_mobs/2005/05/art_ mobs_to_rem.html (retrieved on July 12, 2011).

MCGINNIS, Rebecca. (n/d) Egyptian Tour at the Met 5:32. Full text version at: http:// www.artbeyondsight.org/handbook/text-mcginnis-tour.shtml (retrieved on November 27, 2011).

MIERS, John. (1998) Audio description: Seeing theatre with your ears. Paper presented at the First Annual National Conference on Audio Description, Washington DC. 
PujOL, Joaquim \& Pilar Orero. (2007) "Audiodescription Percursors: Ekphrasis and Narrators." Translation Watch Quarterly 3:2. pp. 49-60.

SCHMEIDler, Emilie \& Corinne Kirchner. (2001) "Adding Audio Description: Does it make a difference?". Journal of Visual Impairment E Blindness, April 2001. pp. 197-212.

SPITZER, Leo. (1962) “The 'Ode on a Grecian Urn' or content vs. metagrammar." In: Hatcher, Anne (ed.) Essays on English and American Literature. Princeton: Princeton University Press. pp. 67-97.

SMith, Richard Donald. (2003) "Museums and verbal description", A Research Project of the Art Education Department, Finland: Jyväskyla University.

VAN DEN BeRG HAARLEM, Dimitry. (2008) "Why do people visit a museum?" Museummarketing.com. Museum marketing blog. (September 24, 2008). Full text version at: http://www.museummarketing.info/2008/09/why-do-people-visita-museum/ (retrieved on July 12, 2011).

YORK, Gregory. (1994/1999) Talking Notes at the Opera. Preliminary Guidelines \& Suggestions for Opera Presenters. Gregory York Productions.

\section{BIONOTE / NOTA BIOGRÁFICA}

\section{Josélia Neves}

Josélia Neves has a degree in Modern Languages and Literatures, an MA in English Studies and a PhD in Translation Studies, with a dissertation on Subtitling for the Deaf and the Hard of Hearing. She teaches at the Instituto Politécnico de Leiria (IPL) and at the Universidade de Coimbra, in Portugal. She has carried out a number of projects within the field of audiovisual translation and sensory accessibility, involving Portuguese broadcasters, distributors and Deaf and/or blind viewers. Apart from publishing a set of guidelines on SDH and another one on $\mathrm{AD}$, which are being used by Portuguese broadcasters, she has published widely in international translation journals and has made regular contributions towards collective volumes. At present she is working on a post doctoral research project, at Imperial College of London, which addresses inclusive communication in museums.

Josélia Neves posee un título de Grado en Lenguas y Literaturas Modernas, un Máster en Estudios Ingleses y un doctorado en Estudios de Traducción, con una tesis sobre el subtitulado para personas sordas y con dificultades de audición. Da clases en el Instituto Politécnico de Leiria (IPL) y en la Universidad de Coimbra, en Portugal. Ha llevado a cabo una serie de proyectos en el ámbito de la traducción audiovisual y accesibilidad sensorial, del que forman 
parte emisoras portuguesas y distribuidores y espectadores sordos o ciegos. Además de la publicación de una serie de directrices sobre subtitulación para sordos y otra en audiodescripción, que están siendo utilizadas por los organismos de radiodifusión portugueses, ha publicado numerosos artículos en revistas internacionales de traducción y ha contribuido regularmente en volúmenes colectivos. En la actualidad se encuentra trabajando en un proyecto de investigación postdoctoral, en el Imperial College de Londres, centrado en la comunicación inclusiva en los museos. 